\title{
GMR
}

\section{Gene organization and characterization of the complete mitogenome of Hypsugo alaschanicus (Chiroptera: Vespertilionidae)}

\author{
J.Y. Kim and Y.C. Park \\ Division of Forest Sciences, College of Forest \& Environmental Sciences, \\ Kangwon National University, Chuncheon, Republic of Korea \\ Corresponding author: Y.C. Park \\ E-mail: parky@kangwon.ac.kr \\ Genet. Mol. Res. 14 (4): 16325-16331 (2015) \\ Received August 11, 2015 \\ Accepted October 7, 2015 \\ Published December 8, 2015 \\ DOI http://dx.doi.org/10.4238/2015.December.8.24
}

\begin{abstract}
We sequenced and characterized the complete mitogenome of Hypsugo alaschanicus (Vespertilionidae) to provide more data for comparative mitogenomics of the genus Hypsugo. The mitogenome of $H$. alaschanicus is a circular molecule of $17,300 \mathrm{bp}$, consisting of a control region and a typically conserved set of 37 vertebrate genes containing 13 protein-coding genes (PCGs), 22 tRNA genes, and two rRNA genes (12S rRNA and 16S rRNA). The mitogenome of $H$. alaschanicus is AT-biased, with a nucleotide composition of $34.1 \mathrm{~A}, 30.9 \mathrm{~T}, 22.4 \mathrm{C}$, and $12.6 \% \mathrm{G}$. In the 13 mitochondrial PCGs of $H$. alaschanicus, the start codon ATG is used in all PCGs, except Nd2 and Nd3 (which use ATT), and Nd5 (which uses ATA). Eight PCGs (Nd1, Cox1, Cox2, Atp8, Atp6, Nd4L, Nd5, and Nd6) use TAA as the stop codon, while the stop codon AGA occurs only in Cytb. Incomplete stop codons (T--) are used in the other four PCGs (Cox3, Nd2, Nd3, and Nd4). These findings contribute to our understanding of the nucleotide composition and molecular evolution of the mitogenomes of the genus Hypsugo, and provide more data for comparative mitogenomics and higher phylogeny in the family Vespertilionidae.
\end{abstract}

Key words: Mitogenome; Gene organization; Hypsugo alaschanicus; Vespertilionidae 


\section{INTRODUCTION}

Bats of the order Chiroptera are the only mammals that can fly. There are more than 1200 species of bat in eighteen families (Simmons, 2005; Myers et al., 2015). Of these, the largest family is the Vespertilionidae, which contains over 300 species (Schnitzler and Kalko, 2001; Simmons, 2005). The mitogenome (mitochondrial DNA) is located in the mitochondria within eukaryotic cells and is maternally inherited. The mutation rate of mitogenomes tends to be higher than that of nuclear genomes. Thus, mitogenomes are useful sources of information for higher phylogenies and molecular evolution (Moritz et al., 1987; Boore, 1999). In a GenBank survey, we found that the mitogenomes of only 17 vespertilionid species have been deposited. The genus Hypsugo, which belongs to the family Vespertilionidae, contains many bats known as pipistrelle bats. The complete mitogenome from this genus has not been sequenced yet. In this study, we sequenced and characterized the complete mitogenome of $H$. alaschanicus (Vespertilionidae) to provide more data for comparative mitogenomics and higher phylogeny of the family Vespertilionidae.

\section{MATERIAL AND METHODS}

\section{Specimen collection and DNA extraction}

$H$. alaschanicus is a widespread species, occurring in the Korean Peninsula, China, Mongolia, and Russia (Smith and Johnston, 2008; Fukui et al., 2013). We caught a $H$. alaschanicus individual in South Korea (Inje, Gangwon-do) using a mist-net (Avinet, Dryden, NY, USA) and extracted total genomic DNA from wing membrane tissue using a DNeasy ${ }^{\circledR}$ Blood and Tissue kit (Qiagen, Valencia, CA, USA).

\section{Primer design, polymerase chain reaction (PCR), and sequencing}

We designed 21 new primer pairs for PCR amplification (Table S1) based on conserved regions from multiple alignments of the complete mitogenomes of Pipistrellus abramus (NC005436) and Chalinolobus tuberculatus (NC002626), available from GenBank. We performed PCR amplification with a final reaction volume of $25 \mu \mathrm{L}$ containing $10 \mathrm{mM}$ Tris- $\mathrm{HCl}, \mathrm{pH} 8.4,50 \mathrm{mM} \mathrm{KCl}$, $4 \mathrm{mM} \mathrm{MgCl}, 200 \mathrm{mM}$ each dNTP, 50 pmol each primer, $2 \cup$ ExTaq polymerase, and $1 \mu \mathrm{L}$ DNA sample. The following cycling conditions were used: denaturation for $5 \mathrm{~min}$ at $94^{\circ} \mathrm{C}$, followed by 30 cycles of denaturation for $1 \mathrm{~min}$ at $94^{\circ} \mathrm{C}$, annealing for $30 \mathrm{~s}$ at 48 to $60^{\circ} \mathrm{C}$, and extension for $1 \mathrm{~min}$ at $72^{\circ} \mathrm{C}$, with a final extension step for $10 \mathrm{~min}$ at $72^{\circ} \mathrm{C}$. PCR products were resolved by electrophoresis on a $1.0 \%$ agarose gel, and extracted using a DNA Gel Extraction kit (Qiagen). Extracted DNA was sent to Biomedic Co. Ltd. (Bucheon, South Korea) for sequencing.

\section{Mitogenome annotation}

The complete mitogenome of $H$. alaschanicus (KT380130) was aligned with that of $P$. abramus and C. tuberculatus using the Clustal-W program in Geneious Pro 5.5 .9 (Biomatters, Auckland, New Zealand). The mitogenome of $H$. alaschanicus was annotated using gene organization information from the latter two mitogenomes. We identified tRNA genes and potential stem-loop secondary structures within these genes using the tRNA scan-SE search server and the ARWEN web server, with default parameters (Lowe and Eddy, 1997; Bernt et al., 2013). 


\section{RESULTS AND DISCUSSION}

\section{Gene organization}

The complete mitogenome of $H$. alaschanicus is $17,300 \mathrm{bp}$ long, with a nucleotide composition of $34.1 \mathrm{~A}, 30.9 \mathrm{~T}, 22.4 \mathrm{C}$, and $12.6 \% \mathrm{G}$, which consists of a control region (CR) and 37 mitochondrial genes, including 13 protein-coding genes (PCGs), 22 tRNA genes, and two rRNA genes (12S rRNA and 16S rRNA). The order and orientation of these genes are identical to those in other bat species (Kim et al., 2011; Nam et al., 2013; Yoon et al., 2013; Wang et al., 2014). On a map of the circular mitogenome of $H$. alaschanicus (Figure 1), nine genes (Nd6 and eight tRNAs) are located on the light strand ( $L$ strand), while the other 29 genes (12 PCGs, 14 tRNAs, and two rRNAs) are located on the heavy strand (H strand).

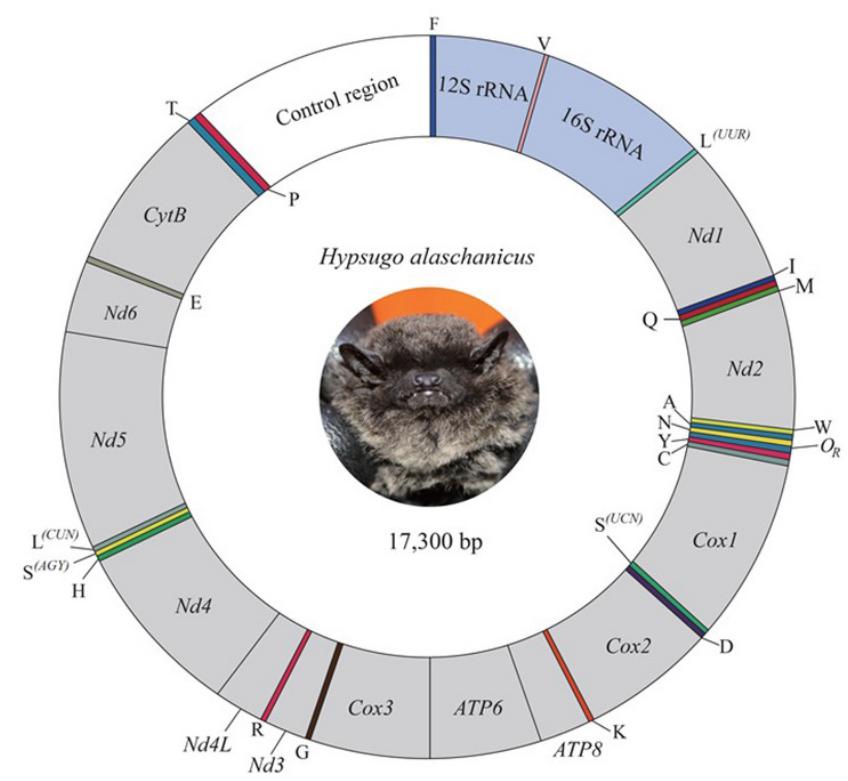

Figure 1. Map of the circular mitogenome of Hypsugo alaschanicus. Genes for tRNAs are denoted by one-letter symbols, according to the IUPAC-IUB single-letter amino acid codes. The replication origin is denoted as $O_{R}$.

\section{Protein-coding genes}

The concatenated size of the 13 mitochondrial PCGs, with the exclusion of stop codons, is $11,376 \mathrm{bp}$, which can be translated into 3792 amino acids. The 13 mitochondrial PCGs in $H$. alaschanicus use the standard start codon (ATN), two types of stop codon (TAA and AGA), and a type of incomplete stop codon (T--) for translation initiation and termination (Table 1). The start codon ATG is used in all PCGs, except $\mathrm{Nd} 2$ and $\mathrm{Nd} 3$ (which use ATT), and Nd5 (which uses ATA). Eight PCGs (Nd1, Cox1, Cox2, Atp8, Atp6, Nd4L, Nd5, and Nd6) use TAA as a stop codon, while the stop codon AGA occurs only in Cytb. The incomplete stop codon (T--) is used in the other four PCGs (Cox3, Nd2, Nd3, and Nd4), which may be completed by poly-adenylation of the 3'-end of the mRNA after transcription (Boore, 1999). 
Table 1. Gene organization and characterization of the Hypsugo alaschanicus mitogenome.

\begin{tabular}{|c|c|c|c|c|c|c|c|}
\hline Gene & Start position & Stop position & Length (bp) & Anticodon & Start codon & Stop codon & Strand \\
\hline tRNA ${ }^{\text {Phe }}$ & 1 & 72 & 72 & GAA & & & + \\
\hline $12 S r R N A$ & 73 & 1027 & 955 & & & & + \\
\hline$t R N A^{\text {Val }}$ & 1028 & 1094 & 67 & TAC & & & + \\
\hline $16 S$ rRNA & 1094 & 2658 & 1565 & & & & + \\
\hline$t R N A^{L e u(U U R)}$ & 2659 & 2733 & 75 & TAA & & & + \\
\hline Nd1 & 2739 & 3695 & 957 & & ATG & TAA & + \\
\hline$t R N A^{l l e}$ & 3695 & 3763 & 69 & GAT & & & + \\
\hline$t R N A^{G / n}$ & 3761 & 3834 & 74 & TTG & & & - \\
\hline tRNA $A^{\text {Met }}$ & 3835 & 3903 & 69 & CAT & & & + \\
\hline$N d 2$ & 3904 & 4945 & 1042 & & ATT & T-- & + \\
\hline$t R N A^{T r p}$ & 4946 & 5012 & 67 & TCA & & & + \\
\hline$t R N A^{A / a}$ & 5017 & 5085 & 69 & TGC & & & - \\
\hline$t R N A^{A s n}$ & 5089 & 5161 & 73 & GTT & & & - \\
\hline$O_{R}$ & 5162 & 5196 & 35 & & & & + \\
\hline$t R N A^{C y s}$ & 5194 & 5260 & 67 & GCA & & & - \\
\hline$t R N A^{T y r}$ & 5261 & 5328 & 68 & GTA & & & - \\
\hline $\operatorname{Cox} 1$ & 5330 & 6874 & 1545 & & ATG & TAA & + \\
\hline $\operatorname{tRN} A^{\operatorname{Ser}(U C N)}$ & 6878 & 6946 & 69 & TGA & & & - \\
\hline$t R N A^{A s p}$ & 6954 & 7020 & 67 & GTC & & & + \\
\hline Cox2 & 7021 & 7704 & 684 & & ATG & TAA & + \\
\hline$t R N A^{L y s}$ & 7708 & 7774 & 67 & TTT & & & + \\
\hline Atp8 & 7776 & 7979 & 204 & & ATG & TAA & + \\
\hline Atp6 & 7937 & 8617 & 681 & & ATG & TAA & + \\
\hline Cox3 & 8617 & 9400 & 784 & & ATG & T-- & + \\
\hline$t R N A^{G / y}$ & 9401 & 9469 & 69 & TCC & & & + \\
\hline $\mathrm{Nd} 3$ & 9470 & 9815 & 346 & & ATT & T-- & + \\
\hline$t R N A^{A r g}$ & 9817 & 9884 & 68 & TCG & & & + \\
\hline$N d 4 L$ & 9886 & 10,182 & 297 & & ATG & TAA & + \\
\hline$N d 4$ & 10,176 & 11,553 & 1378 & & ATG & T-- & + \\
\hline$t R N A^{\text {His }}$ & 11,554 & 11,621 & 68 & GTG & & & + \\
\hline $\operatorname{tRNA} A^{\operatorname{Ser}(A G Y)}$ & 11,622 & 11,680 & 59 & GCT & & & + \\
\hline$t R N A^{L e u(C U N)}$ & 11,682 & 11,751 & 70 & TAG & & & + \\
\hline Nd5 & 11,752 & 13,572 & 1821 & & ATA & TAA & + \\
\hline Nd6 & 13,556 & 14,083 & 528 & & ATG & TAA & - \\
\hline tRNA $A^{G / u}$ & 14,084 & 14,153 & 70 & TTC & & & - \\
\hline Cytb & 14,157 & 15,296 & 1140 & & ATG & AGA & + \\
\hline tRNA $A^{T h r}$ & 15,297 & 15,365 & 69 & TGT & & & + \\
\hline$t R N A^{\text {Pro }}$ & 15,365 & 15,431 & 67 & TGG & & & - \\
\hline Control region & 15,432 & 17,300 & 1869 & & & & + \\
\hline
\end{tabular}

-The heavy $(\mathrm{H})$ and light $(\mathrm{L})$ strands are denoted by the strand ' + ' and '-', respectively.

\section{rRNA genes and tRNA genes}

The combined size of the two rRNA genes (12S rRNA and $16 S$ rRNA) is $2520 \mathrm{bp}$. As shown in other bat mitogenomes (Kim et al., 2011; Nam et al., 2013; Yoon et al., 2013; Wang et al., 2014), the two rRNA genes of the $H$. alaschanicus mitogenome are located between $t R N A^{\text {Phe }}$

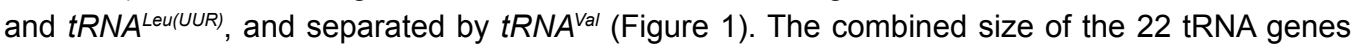
is $1513 \mathrm{bp}$. The 22 tRNA genes range in size from 59 (tRNA $A^{\text {Ser(AGY) }}$ ) to $75 \mathrm{bp}$ (tRNA ${ }^{\text {Leu(UUR); }}$ Table 1). The secondary structures of tRNA genes are shown in Figure 2. The tRNA genes include two leucine-tRNA genes ( $t R N A^{\text {Leu(UUR) }}$ and $\left.t R N A^{\text {Leu(CUN) }}\right)$ and two serine-tRNA genes ( $t R N A^{\text {Ser(UCN) }}$ and $\left.t R N A^{\text {Ser }(A G V)}\right)$. Of the 22 tRNA genes, 21 can be folded into the canonical cloverleaf secondary structure. In $t R N A^{\text {Ser(AGY) }}$, however, the DHU arm has been deleted. 

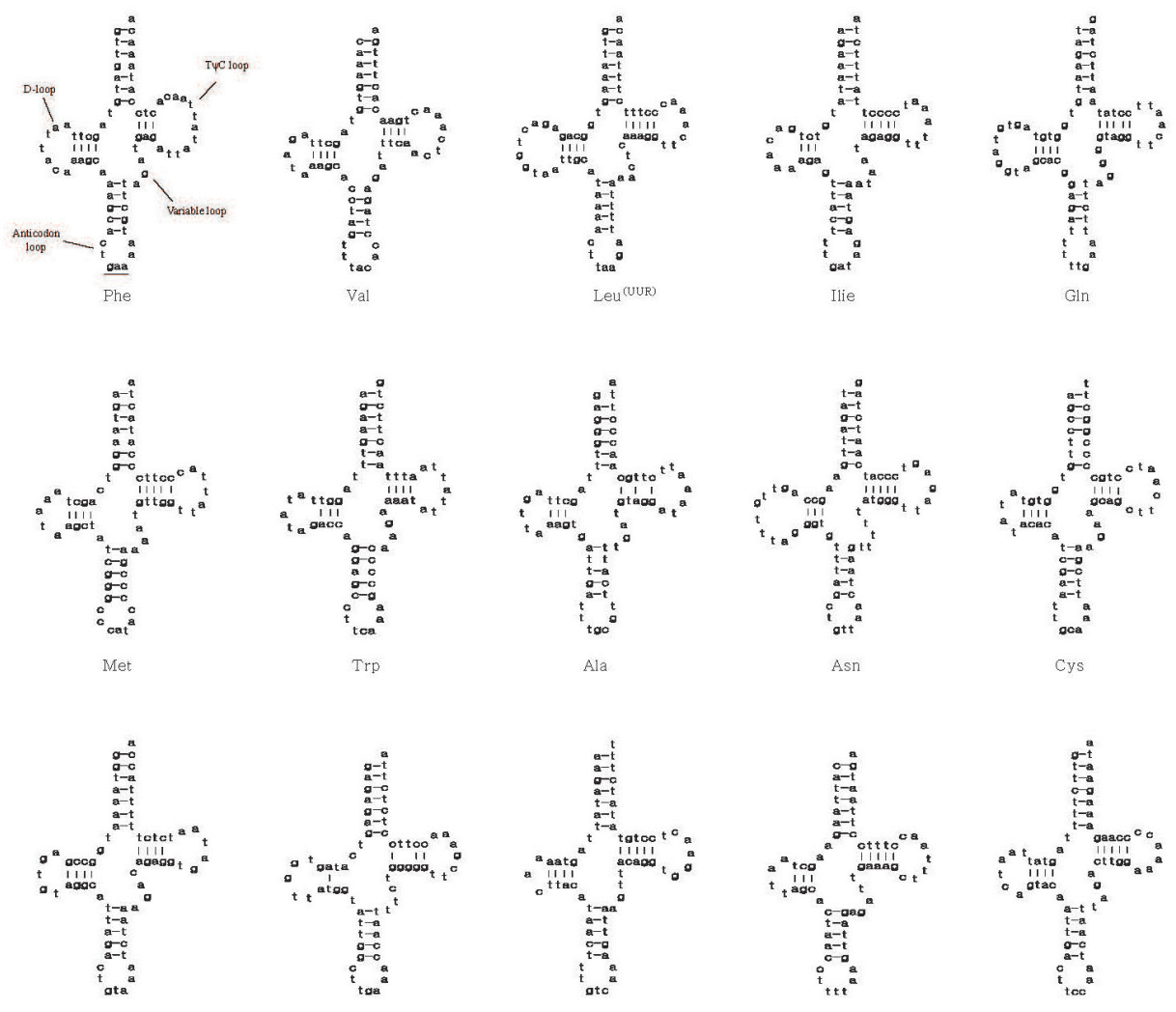

Tyr

Ser(UGM)

Asp

Lys

Gly
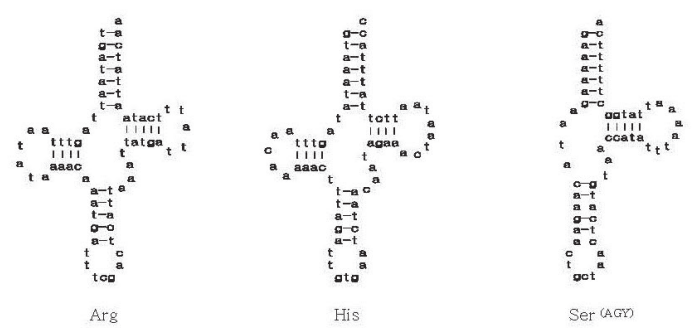

Ser (AGX)
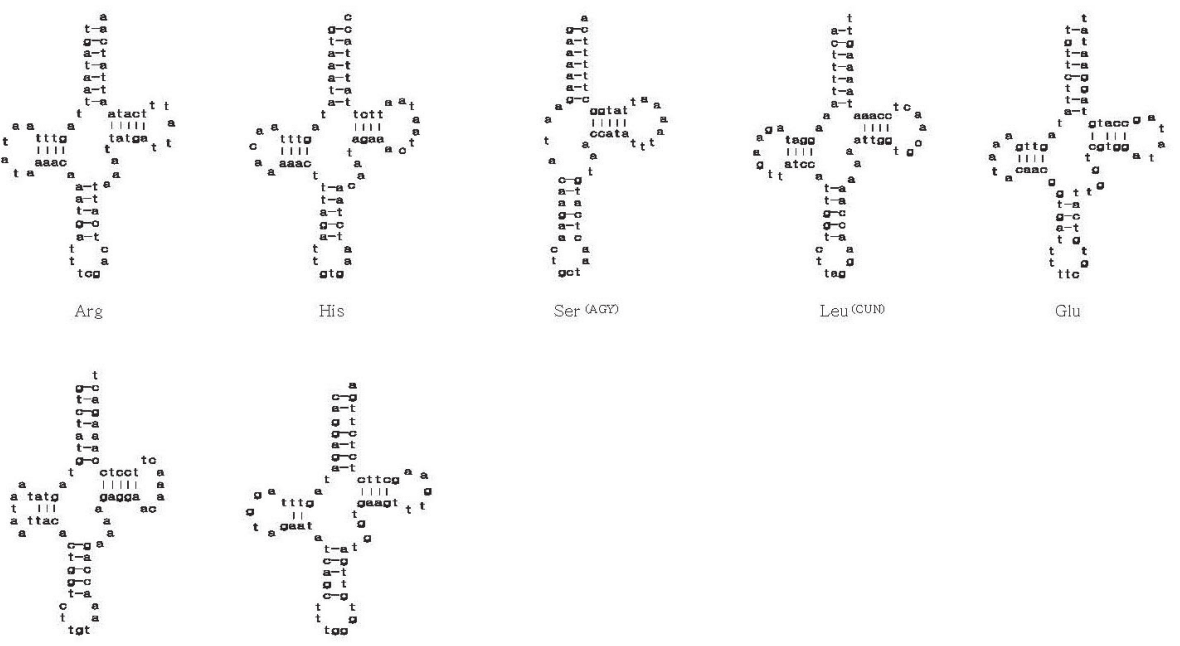

Leu(CUN)

Glu

Figure 2. Secondary structures of the 22 mitochondrial tRNA genes of Hypsugo alaschanicus. The $\mathrm{H}$ strand in the outer circle encodes 14 genes, and the $L$ strand in the inner circle encodes 8 genes. 


\section{Noncoding regions}

The mitochondrial replication origin $\left(O_{R}\right)$ plays an important role in mitogenome replication. The mitochondrial $O_{R}$ of $H$. alaschanicus is $35 \mathrm{bp}$ long and is located between $t R N A^{A s n}$ and $t R N A^{c y s}$ in the WANCY region (cluster region of $t R N A^{T r p}, t R N A^{\text {Ala }}, t R N A^{A s n}, t R N A^{\text {cys }}$, and $t R N A^{\text {Tyr }}$; Figure 1). The CR of the $H$. alaschanicus mitogenome is $1869 \mathrm{bp}$ long and is located between $t R N A^{\text {Pro }}$ and tRNA ${ }^{\text {Phe }}$ (Figure 1), as described in other bat mitogenomes (Kim et al., 2011; Nam et al., 2013; Yoon et al., 2013; Wang et al., 2014). Intergenic spacers were found at 12 sites in the $H$. alaschanicus mitogenome (Table 1). The intergenic spacers range in size from a single-bp spacer (between $t R N A^{T y r}$ and Cox1, tRNA ${ }^{L y s}$ and Atp8, Nd3 and $t R N A^{A r g}, t R N A^{A r g}$ and $N d 4 L$, and $t R N A^{\text {Ser(AGY) }}$ and $t R N A^{\text {Leu(CUN) })}$ to a 7-bp spacer (between $t R N A^{\text {Ser(UCN) }}$ and $t R N A^{A s p}$ ). Intergenic spacers 3 bp long were found at four sites (between $t R N A^{A l a}$ and $t R N A^{A s n}$, Cox 1 and $t R N A^{\operatorname{Ser}(U C N)}$, Cox 2 and $t R N A^{\text {Lys }}$, and $t R N A^{\text {Glu }}$ and $C y t b$ ), while intergenic spaces 4 bp and 5 bp long were present only once (between $t R N A^{T r p}$ and $t R N A^{A l a}$, and between $t R N A^{\text {Leu(UUR) }}$ and $N d 1$, respectively). The combined size of all 12 intergenic spacers was $33 \mathrm{bp}$. Such intergenic spacers have also been observed in various bat mitogenomes (Kim et al., 2011; Nam et al., 2013; Yoon et al., 2013; Wang et al., 2014).

In conclusion, our study presents gene organization and characteristics of the complete mitogenome of $H$. alaschanicus. The mitogenome of $H$. alaschanicus is a circular molecule of $17,300 \mathrm{bp}$, with a nucleotide composition of $34.1 \mathrm{~A}, 30.9 \mathrm{~T}, 22.4 \mathrm{C}$, and $12.6 \% \mathrm{G}$, which contains a control region and a typical set of 37 vertebrate mitochondrial genes containing 13 PCGs, 22 tRNA genes, and two rRNA genes (12S rRNA and 16S rRNA). The gene order and organization of the $H$. alaschanicus mitogenome follow typical patterns found in bat mitogenomes. These findings contribute to our understanding of the nucleotide composition and molecular evolution of the mitogenomes of the genus Hypsugo, and will provide more data for comparative mitogenomics and higher phylogeny in the family Vespertilionidae.

\section{Conflicts of interest}

The authors declare no conflict of interest.

\section{ACKNOWLEDGMENTS}

This study was supported by a grant from the National Research Foundation of Korea (NRF) Joint Research Program (\#2013K2A1A2055207).

\section{Supplementary material}

\section{REFERENCES}

Bernt M, Donath A, Jühling F, Externbrink F, et al. (2013). MITOS: improved de novo metazoan mitochondrial genome annotation. Mol. Phylogenet. Evol. 69: 313-319.

Boore JL (1999). Animal mitochondrial genomes. Nucleic Acids Res. 27: 1767-1780.

Fukui D, Mochida M, Yamamoto A and Kawai K (2013). Roost and echolocation call structure of the Alashanian pipistrelle Hypsugo alaschanicus: first confirmation as a resident species in Japan. Mamm. Study 38: 61-66.

Kim YM, Choi EH, Kim SK, Jang KH, et al. (2011). Complete mitochondrial genome of the Hodgson's bat Myotis formosus (Mammalia, Chiroptera, Vespertilionidae). Mitochondrial DNA 22: 71-73.

Lowe TM and Eddy SR (1997). tRNAscan-SE: a program for improved detection of transfer RNA genes in genomic sequence. Nucleic Acids Res. 25: 955-964. 
Moritz C, Dowling TE and Brown WM (1987). Evolution of animal mitochondrial DNA: relevance for population biology and systematics. Ann. Rev. Ecol. Syst. 18: 269-292.

Myers P, Esponosa R, Parr CS, Jones T, et al. (2015). The animal diversity web (online). Available at [http://animaldiversity. org]. Accessed May 25, 2015.

Nam TW, Kim HR, Cho JY and Park YC (2013). Complete mitochondrial genome of a large-footed bat, Myotis macrodactylus (Vespertilionidae). Mitochondrial DNA 26: 661-662.

Schnitzler HU and Kalko EKV (2001). Echolocation by insect-eating bats. Bioscience 51: 557-569.

Simmons NB (2005). Order Chiroptera. In: Mammal species of the world (Wilson DE and. Reeder DM, eds). John Hopkins University Press, Baltimore.

Smith AT and Johnston CH (2008). Pipistrellus alaschanicus. The IUCN red list of threatened species. Version 2015. 2. www. iucnredlist.org. Accessed August 9, 2015.

Wang SQ, Li YJ, Yin AG, Zhang W, et al. (2014). The complete mitochondrial genome of David's myotis, Myotis davidii (Myotis, Vespertilionidae). Mitochondrial DNA 10: 1-2.

Yoon KB, Cho JY and Park YC (2013). Complete mitochondrial genome of the Korean ikonnikov's bat Myotis ikonnikovi (Chiroptera: Vespertilionidae). Mitochondrial DNA 26: 274-275. 